\title{
The Calm Before The Storm?
}

Early Republican Classical Literature and the Making of Chinese Modernity

\section{Joachim Boittout}

\section{(2) OpenEdition}

\section{Journals}

Electronic version

URL: http://journals.openedition.org/chinaperspectives/9206

DOI: 10.4000/chinaperspectives.9206

ISSN: 1996-4617

\section{Publisher}

Centre d'étude français sur la Chine contemporaine

Printed version

Date of publication: 8 June 2019

Number of pages: $75-80$

ISSN: 2070-3449

\section{Electronic reference}

Joachim Boittout, "The Calm Before The Storm? », China Perspectives [Online], 2019-2 | 2019, Online since 10 June 2019, connection on 19 December 2020. URL : http://journals.openedition.org/ chinaperspectives/9206; DOI : https://doi.org/10.4000/chinaperspectives.9206 


\title{
The Calm Before The Storm?
}

\author{
Early Republican Classical Literature and the Making of Chinese Modernity
}

\author{
IOACHIM BOITTOUT (1)
}

\begin{abstract}
This article revisits intellectual and literary trends in the few years preceding the launch of the New Culture Movement. Focusing on translations of texts dating from 1912 to 1915 , this study explores how a group of writers usually considered conservative ventured to question the reliance of the individual on political structures that underpinned the then prevailing intellectual framework. I argue that these texts competed through literary means and preceded the claim of self-awareness forcibly voiced by New Culture activists in 1915 by achieving what I call a turn to the intimate. Reassessing the necessity to translate these texts as we celebrate this year the centenary of May Fourth Movement, this approach seeks to resurrect the long-forgotten but thriving literary and intellectual context from which the New Culture Movement's ideas sprouted.
\end{abstract}

KEYWORDS: New Culture Movement, Minquanbao, turn to the intimate, Xu Zhenya, Wu Shuangre, Xu Tianxiao, translation.

\section{Toward a reassessment of Early Republican public sphere: The "forgotten" 1910s}

$\mathrm{O}$ $\mathrm{n}$ the centenary of May Fourth and with some hindsight, this article investigates what happened in the field of literary production a couple of years before 1919. More than 20 years ago, David Derwei Wang's seminal study on Late Qing popular fiction forcefully demonstrated that New Culture intellectuals' radical agenda and redefinition of traditional cultural values were rooted in what used to be a marginalised literary tradition (Wang 1997). Ranging from chivalry novels to sentimental fiction and including castigation novels about corrupt officialdom, the literary production of the late nineteenth century did infuse the literary realm with political and social dissent that spread into the public sphere with the help of burgeoning print capitalism in treaty port cities. (2)

However, most literary histories fall short on accounting for the critical years between the foundation of the Republic of China - the first republic in Asia - and 1919. The launching of New Youth and the "Call to the Youth" ( Jinggao qingnian 敬告青年) of Chen Duxiu 陳獨秀 (1879-1942) has rightfully attracted most of the scholarly attention. Nevertheless, one must not forget that the nature of the disruption resulting from the launch of the New Culture Movement was actually less substantial than its proponents have claimed. In those days, New Culture's propagandists found themselves competing with numerous newspapers, magazines, and journals as they were taking a leading role in the shaping of public opinion and the intellectual agenda on political and cultural issues. As described in earlier studies, New Youth was elitist in nature, and so were its competing popular literary publications. ${ }^{(3)}$ Therefore, New Youth, far from being the leading magazine of the day, was only one among other influential publications (Hockx 2003), (4) but this is in no way a negation of its seminal input to what can roughly be labelled as "Chinese modernity."

This useful reminder urges us to reconsider the intellectual and literary production context of its original release, as we might (re)discover that its competing publications were actually engaged in discussions that, for some of them, pertained to similar issues and even reached similar conclusions as New Culture's activists. However, the point of such a re-evaluation is not to refashion literary history of the early Republican era as a necessary precedent for modern democratic enlightenment brought by Chen Duxiu and others. By introducing a selection of literary publications of the early Republican era (1912-1916), I aim to show that, through completely different formal means and not without contradictions, ${ }^{(5)}$ a group of popular writers and journalists endeavoured to scrutinise and reassess some dominant Confucian values. Some of these values happened to be under heavy fire from New Youth at the same time. They also ventured as far as questioning the philosophical grounds of an autonomous self, torn between family duties and commitment to the Republic. It is worth noting that these writers relied on the very classical literary means that were disparagingly dismissed by Chen Duxiu in the 1917 "Discourse on the Literary Revolution" (Geming wenxue lun 文學革命論). Operating on a long-established horizon of expectation in which classical forms and tropes matched both the tastes and the habits of a literate audience, early Republican writers made use of such expectations and knowledge to frame their thoughts and increase their readership. May Fourth's centenary thus seems a timely occasion to examine the diversity of the literary publications assertively challenged by New Culture activists (Wang 1999). This undertaking would enable us to understand how some of the literati casted by New Culture activists as petty mercantile writers and, for that matter, as callous and immoral writers (Feng 1996; Bärthlein 1999; Chen 2008: 53-6), did partake precociously in an oblique inquiry on Chinese political modernity. And as they are yet to be better known, this anniversary could also be the opportunity to share some of their - numerous - texts so that we can get a firmer grasp on their works.

\footnotetext{
1. I am very grateful to Sebastian Veg for all his suggestions.

. On Chinese print capitalism and early newspapers, see Wagner (2007) and Reed (2004).

On popular literature of the 1910s and the 1920s, see Link (1981).

4. See also Wang Xiaoming's seminal article on how New Youth successfully challenged the leading position that prominent journals were enjoying in the field of cultural production (Wang 1999). See also Wang Hui (2013).

5. On the conservative aspects of Mandarin and Butterfly writers' writing, see among others Lee
} (2007). 
It is based on these observations that I depart from Xu jilin's 許紀霖 definition of the Chinese public sphere, from which he excludes literary works. Drawing on the Habermasian concept, $\mathrm{Xu}$ jilin denies any critical ability to non-politically related works. A clear-cut separation between what he describes as rational political essays and literary publications does not stand in this context, as far as their political significance is concerned. As my close reading of early 1910 s newspapers reveals, short stories, novels, and virtually uncountable short pieces published in literary supplements were embedded in political discussions. Besides, many of these writers also worked as political journalists, and some of them even published "rational" and polemical essays on a weekly basis in prominent newspapers. Thus, it does not seem quite fair to deprive them of their role in the shaping of public opinion ( $\mathrm{Xu}$ 2011: 89-90; Fang 2001: 71).

Acting as leading figures of what was later ironically and scornfully labelled as the "Mandarin Ducks and Butterflies" group (Feng 1996: 176-81), Xu Zhenya 徐枕亞 (1889-1937), Wu Shuangre 吳雙熱 (1885-1934), Xu Tianxiao 徐天嘯 (1886-1941), Li Dingyi 李定夷 (1890-1963), and Liu Tieleng 劉鐵冷 (1881-1961) enjoyed tremendous success during that decade. Xu Zhenya's bestseller, Yulihun 玉梨魂 or The Jade Pear's Spirit (1912), is reported to be one of the - if not the - most printed book of the Republican era. ${ }^{(6)}$ It is critical to remember that these writers were first and foremost journalists and that, as Bao Tianxiao 包天笑 (1876-1973), another wellknown popular writer of those days, recollects in his memoirs, a complete confusion between the two identities prevailed in the 1900s and 1910s. ${ }^{(7)}$ This feature of the early Republican literary realm, in which literati would work both as political journalists and serial novelists, arguably widened the general misunderstanding about their public commitment. One would hardly be able to appreciate the full meaning of their literary works without - at least - considering the content of their numerous political pamphlets and other pieces, mostly scattered in the following publications.

Among their three main strongholds, People's Rights or Democracy (Minquanbao 民權報) was probably the most famous. It was distributed daily from March 1912 to January 1914. Based in Shanghai and affiliated with the Tongmenghui 同盟會 and then the Kuomintang (KMT), it was run by Zhou Shaoheng 周少衡, alias Zhou Hao 周浩. It virtually clustered all of the early Butterfly writers. Along with Celestial Bell (Tianduobao 天鐸報), led by Li Huaishuang 李懷霜 (1874-1950), and People's Report of China (Zhonghuaminbao 中華民報), run by Deng Jiayan 鄧家彥 (1883-1966), it was the fiercest opponent to Yuan Shikai 袁世凱 (1859-1916) during the first years of the Republic. These newspapers are of critical importance to fully understanding the multiple dimensions of Butterfly writers' work, the authors being, during that time, first and foremost political journalists. The literary supplement of People's Rights, although far from the oldest in the history of Chinese media, greatly renovated the existing framework by enriching its content and raising it to a more political dimension. From the very beginning, it concentrated the most vitriolic attacks against Yuan Shikai's power as well as the most passionate statements defending democracy. When it became evident that Yuan was not ready to abide by the democratic laws enshrined in the Provisional Constitution and publicly enacted during the national elections of 1912-1914 (Young 1977: 113-23, 138-76), Xu Zhenya and others launched countless assaults on his administration in People's Rights. Dismissing political compromise such as it was understood and upheld in 1912 in other Tongmenghui newspapers such as People Stand (Minlibao 民立報), ${ }^{(8)}$ they relentlessly targeted what they deemed the evil residue of autocracy, hallmarking their writing as new and modern. This feature should remind us that radicalism - at least in a discursive form - stems from the late Qing and early Republican press. Contrary to what is often believed, the early Republican public arena witnessed many violent clashes between newspapers seeking hegemony in the field. ${ }^{(9)}$ Elements of People's Rights (Minquansu 民權素) ran from 1914 to 1917. It was established after the demise of People's Rights, shut down by Yuan Shikai in January 1914 after months of struggling. Although a literary magazine of serial novels and short stories, it also strived to keep on fighting Yuan's power through humoristic short pieces and poems. Finally, The Grove of Novels (Xiaoshuocongbao 小說叢報) outlasted the two other publications, as it maintained publication from 1914 to 1919. This magazine is viewed - usually in a dismissive way - as the other stronghold of Butterfly writers. It published many short stories composed in parallel prose, and continued, even after the shutdown of People's Rights, to tackle contemporary issues. It serialised a fairly high number of war-related texts, mostly recounting recent events such as the Taiping Rebellion (1850-1864) and the 1911 Wuchang Uprising, fostering an emotional collective memory of upheavals that were critical in reshaping the political order of China, however traumatic they might have been.

\section{Reassessing the nation: An enquiry about individual freedom in Butterfly writings of the early 1910 s}

Among the overwhelming number of sentimental works infusing the literary arena of the early 1910s, pathetic depictions of tragic individual fates arguably took the lion's share of the production. In the meantime, a great deal of these works also exalted national sentiments and the need to build a modern society. In this context, it is particularly relevant to examine how Butterfly writers perceived the literary representation of individuals and the way they linked it to the nurturing of a national sentiment. In other words, was there any kind of hierarchy between these two kinds of strongly intertwined sentiments? Did the national sentiment with which Butterfly writers were filling their pages take moral precedence over individual torments? The question is even more worth asking as, just between 1914 and 1916, the first resounding essays by Chen Duxiu related to nationalism and the self (Aiguoxin yu zijuexin 愛國心與自覺心) were published in Tiger (Jiayin zazhi 甲寅雜誌) and then in Youth Magazine (Qingnian zazhi 青年雜誌) (Weston 1998: 272-6).

In 1914, a Tiger reader would probably not have been struck to discover in The Grove of Novels a short story echoing Chen's fundamental query about the relationship between the individual and the state (assuming that he would also read this middle-brow magazine). In a three-page-long short story written under the penname of Jue 覺 (possibly Xu Zhenya, whose real

6. According to C. T. Hsia (1982)

7. See for instance Chapter 68 (Xinwen jizhe kaichang 新聞記者開場) of his memoirs: Chuanyinglou huiyilu 釧影樓回憶錄.

8. People Stand was started in Shanghai by Yu Youren 于右任 (1879-1964) and was designed to be the mouthpiece of the Tongmenghui, then the KMT after it was established in August 1912.

9. One of the fiercest fights took place between July and September 1912. It mainly opposed Dai Jitao 戴季陶, by then one of the leading editorialists of People's Rights, and a prominent figure of People's Stand, Zhang Shizhao 章士釗 (sided by Yu Youren 于右任, the newspapers' chief editor). Although technically on the same political side, People's Rights launched reckless assaults on its sister paper, venturing as far as casting scornful doubts about Zhang Shizhao's mental capacity to understand complex constitutional issues such as the structure of a Presidential regime. Zhang was simultaneously targeted by Dai litao for controversially suggesting the suppression of the many political parties spawned by the establishment of the Republic in a July 1912 People's Stand's article (Shen 1986: 173-6). 
name was Xu Jue 徐覺) published in 1914 and entitled "A Plum" (Yike mei 一顆梅), we read a sentimental introspection of a young revolutionary. Having left the woman he loves to join the 1911 Revolution, he finds himself wandering home after several years of disappointing political commitment to a cause he no longer believes in. Filled with remorse and ashamed to have failed at becoming a hero, he eventually chooses what he perceives to be the last option: reclusion until death. At the core of this puzzling brief short story lies a disillusioned meditation on the meaning of self-sacrifice for public causes. Indeed, by turning down personal love to experience a greater love for the nation, the narrator refused to yield to his private feelings. But, he concludes, devotion to the nation and political commitment are not worth sacrificing one's intimate sentiments and aspirations. His tragic experience leaves him the bitter taste of a wasted life and unanswerable questions. Here goes the main part of the short story (see excerpt 1).
Butterfly writers, who all witnessed and sometimes even actively participated in the Xinhai Revolution, like He Haiming 何海鳴 (Cai 2017: 4-16), were already engaged in an entangled re-evaluation of individual freedom. As the fragile and new liberties obtained in 1912 rapidly became endangered under Yuan Shikai's dictatorship, the question of individual commitment to the nation-building process (embedded in the Confucian moral duty to serve one's country) became pervasive in their works, especially from 1913 onwards. Witnessing the failure of the Second Revolution (JulySeptember 1913) and the rapid discarding of ill-fated republican institutions, they questioned what Chen Duxiu labels as "patriotism" in the aforementioned article, and in "Do we actually have to be patriotic?" (Women jiujing yingdang bu yingdang aiguo 我們究竟應當不應當愛國), published in June 1919 in Weekly Critic (Meizhou pinglun 每週評論). Chen provides the reader with an answer in both articles, as he claims, in sub-

Excerpt 1: Jue 覺, "一顆梅" (Yike mei, A Plum), The Grove of Novels (Xiaoshuo congbao 小說叢報), 1914.

"When I was twenty years old I married my wife, lingnong. For one year, I literally bathed in love and had a full taste of what we call family happiness. (...) I mean, I enjoy this kind of softness, but I could not live my entire life in this countryside. And then I got another wife, an ideal one, whose name was China. Before, my love used to be focused on one single person, but from this time I started extending it to the entire country. (...) My wife, feeling grief because of it, told me: "The barbarians [i.e. the Manchus] have not been exterminated yet, what's the meaning of staying at home? Go, my dear, I know you're not the kind of man who yearns for the lovely sight of his countryside." Full of energy and vigour, I did not hesitate and walked out the door ready to fight.

(...) I did not write at all, probably because I was still obsessed with the other ideal wife I bore in my heart and in my mind. (...) But today the country has yet to be transformed and all I see around is desolation; there is no place where I could make use of this great love anymore. Confronted with such a hopeless situation, I was overwhelmed with grief. However, all my sorrow couldn't change anything, so I figured that the time was right: let's go home, let's go home! Then I reduced the scope of my love so that it only applies to my wife. I was feeling like someone who discovered himself still alive after a long retreat. (...) But little did I know that all of this was but the mere product of my imagination: reality happened to be quite different! I once left home for the sake of the country, and now that there is nothing that can be done for it, I want to leave the country and speak about my family. Alas, there is not much to talk about my family anymore either!

The spirit of the hero is gone, and the sentiments of the lover are hurt. People like me are what they call both failed heroes and failed lovers. (...) I was willing to come home, but the roads to my home were blocked. I was willing to meet Jingnong again, but the link that used to bind us did not exist anymore. (...) And now that I was going home in such a pitiful state, Jingnong would certainly refuse to see me. And could I see her? Not to mention the fact that during the past years hardships of all kinds did not spare my family. Amidst the constantly changing political situation, a new regime, worthy of the name, emerged, which was already threaten by all sorts of obstacles. Jingnong, who had been drawn into this turmoil, experienced considerable torments. Alas, poor Jingnong, I let you down!"

A doubly failed "hero" - private sentimentality being, in Butterfly writings, the main prerequisite to becoming a political hero - the narrator is at a loss with what to do next in his life. Now that he's lost the only kind of love that actually turns out to matter, i.e., the private sentiments for his wife, he realises that his previous choice implied renouncing his individual happiness. In this short story, love and - failed - political commitment are deeply intertwined and symbolise the two possibilities that, surprisingly enough in a Butterfly story, are mutually exclusive: embracing the nation's fate or favouring individual freedom and happiness. While the first one was the moral choice to make, the second option proved to be the sounder one, though ostensibly more selfish.

This short story is just one of many war-related writings published in the aforementioned literary magazines, all dealing in their own way with the same daunting question voiced by Chen Duxiu in the opening editorial of Youth Magazine a year later: "what is self-awareness?" (Chow 1960: 45). As we can see from the short story, the answer given by Chen in his "Call to Youth" could hardly appear as a totally disruptive statement: "It is to be conscious of the value and responsibility of one's young life and vitality, to maintain one's self-respect, which should not be lowered" (ibid:. 46). Indeed, stance, that it's only worth being patriotic or even giving one's life for the country if this country ensures the happiness of its people and if the government does not make use of patriotic feelings to launch wars. At the same time, he does not deny the moral soundness of self-preservation when it is the result of profound thinking. Preserving one's own rational thinking proves to be a way to resist the emotional appeal to patriotic feelings that can easily be misused. The short story partially translated here does not go as far as Chen Duxiu's articles, which castigate the absence of true patriotism in China. Nonetheless, its ambiguous ending does question the meaning of an emotionally-fuelled patriotism. Here, the author seems to assert the value of the private ( $s i$ 私) during the very moment of national community-making. He reminds the reader that political participation of the "greater self" should not obliterate the dignity of the "smaller self."

However, the reluctance of Butterfly writers to provide the audience with a straight and definite answer to this thorny issue proved to be less telling than the literary move they undertook during these years. Choosing to put a new emphasis on their own private lives, they displayed a different kind of self-awareness, favouring the depiction of intimate scenes. I label this 
trend a "turn to the intimate." Differing from both the late Qing fiction's sentimentalism and intimate psychological inquiries suffusing May Fourth literature and the Shanghainese neo-sensationalism of the 1920s, these works tend to focus on trivial anecdotes pertaining to the author's private life. Strongly biographical - the early 1910s witnessing the rapid spread of published intimate diaries - this trend thrived on the literary pages of newspapers and, from 1914 onwards, in literary magazines.

\section{Neither the self-awareness nor egotism of New Culture: The turn to the intimate}

A close reading of Butterfly publications between 1912 and 1916 reveals a literary infatuation for self-centred texts. This trend, which sees Xu Zhenya, Wu Shuangre, and Xu Tianxiao portraying themselves in everyday life situations or recalling intimate memories, does more than betray a self-fashioning turn (Chen 2015: 89-90). Equally critical in these intimate and often funny fragments of their lives is the conscious attention to the self, considered here in its more - apparently - futile features. Taking a step back from the abstract dissertations pertaining to the great picture, i.e., the political upheaval that transformed the country (at least on an institutional level), they chose to focus on ordinary life as it is experienced at a grass-roots level. It could be their own lives or those of humble people, mostly peasants with whom they became acquainted during their early teaching careers in the countryside of Changshu 常熟. Reassessing the meaning of political events through an intimate lens, these writers provide many vivid depictions of life before and after 1911, while successfully including themselves and their family history in the greater narrative of the nation. Thus, through these public-oriented private pieces, they achieve a double intellectual realisation by performing their writing task as individuals per se and, at the same time, as full members of the national community. While these writings were always keen on playing with the reader's sentiments, it is worth noting that their dominant tone is not the tragic, heart-breaking sound of frustrated lovers or saddened citizens feeling the demise of the Republic. They usually display a fairly enjoyable sense of humour, revealing another facet of Butterfly writing, which has yet to be explored more systematically. ${ }^{(10)}$ Here is one example of this trend, with an excerpt from Wu Shuangre's early childhood recollection (see excerpt 2). what Wu tells us, providing the reader with a highly hyperbolic and comic account of the trip. Beyond the evident literary and commercial appeal to the readership lies a deeper layer of analysis: the shared belief that petty individual lives matter, and that they can influence how readers think about their own lives in an era of tremendous transformation. In this context, re-evaluating through literary means - the value and depth of trivial events counterbalances the serious political discussions (or lun 論) published in the front page. In this particular case, Xu Tianxiao's hard trip echoes the Republic's, which in August 1913 was being rocked by the Second Revolution. But instead of picturing how political turmoil crushed fragile lives, Wu Shuangre chooses to parallel the nation's torments with those of feeble literati in an effort to humorously adjust the narrative of national upheaval to the meaningless hardships experienced by a petty individual. Here is an example of how Wu echoes national events in the private realm. The discrepancy between the seriousness of the current political situation and the absurd trials of Xu Tianxiao arguably serves as comic relief. At the same time, Wu reaffirms the need to include individual stories in national narratives (see excerpt 3).

\section{Conclusion: "Tiny waves over stagnant water"}

To conclude, I borrow an image from the great Sichuanese writer Li Jieren 李劼人 (1891-1962).(11) Li used this title to recount the imperceptible social transformations occurring in a small town in the outskirts of Chengdu between 1894 and 1901, before the outburst of 1911. ${ }^{(12)}$ Here, by focusing on the fields of the literary and journalistic production of the few years preceding the New Culture Movement and the stormy spring of 1919, I wanted to contribute to the re-evaluation of what we can call the "left-behinds" of May Fourth. Discarded by iconoclast writers and overshadowed by late Qing vernacular authors, writers of the early Republic have long been kept in the dark. Despite some extremely erudite and stimulating academic works devoted to them, their contribution to Chinese modernity remains to be fully assessed.

In this article, I tried to pinpoint a few "tiny waves", their short stories and essays brought to the Chinese audience prior to and during the Enlightenment project of May Fourth activists. Grounding political participation in a sentimental self-realisation, they faced daunting difficulties figuring out what was most important between the individual and the nation. Recklessly at odds with Yuan Shikai's regime, they kept on cherishing

Excerpt 2: Wu Shuangre 吳雙熱 “余之家庭” (Yu zhi jiating, My Family), Minquan bao 民權報, 9 September 1913.

"Everybody has a family, but family life leads eight or nine families out of ten to experience hardship. Parents lose their kindness, children stop being respectful, love between brothers and affection between couples fades away. And so does harmony between aunts and uncles. When this happens, the family never fails to become a place full of noise and insults, which inevitably generates quite a lot of sorrow. Luckily enough, my family wasn't like this.

We were a small family. It was I, my mother, the second spouse of my father, and her son. I didn't have any uncle or brother (just one sister, who was married to Wu Zhongwang. Her husband passed away when he was still young, and she decided to establish a school for women, named Pingyang, before returning to our home one year after). The fact that I didn't have any uncle or brother probably spared us many domestic torments. The four of us used to diligently fulfil our moral duties, making us a truly harmonious and Republican family. Elders didn't act like despots with young ones, and young people didn't behave with arrogance. Never did we hear a single sound of fighting or discontent. The only one who was invariably making a sad face, no matter how many smiles we could give him, was the portrait of... our ancestor!"

In another humorous piece, Wu Shuangre narrates the "hard trip" undertaken by Xu Tianxiao to reach the school where they were both teaching. Located in the countryside on the outskirts of Changshu, from which Xu departs, what is supposed to be a normal journey turns into an adventure. This is, at least,
10. For a compelling inquiry into the literary and political power of laughter in Republican China, see Rea (2015).

11. Known as a prominent May Fourth activist.

12. For a thorough analysis of Li's trilogy, see $\mathrm{Ng}$ (2015). 
Excerpt 3: Wu Shuangre 吳雙熱, “苦旅行” (Ku lüxing, A hard trip), Minquanbao 民權報, 27 August 1913.

"Look at all the great explorers in the history of mankind, who ventured thousands of miles away from their home and never uttered the slightest complaint. And have a look at Tianxiao: he just went on a trip from Yushan to Hushang. More specifically, from the old garden near the Huangban bridge of Yushan to the Zou private school, which is not even 20 miles away. And half of this 20-mile-long journey was made by boat. He must have walked at most two or three miles! It's already weird enough to call this journey a trip, but a "hard" trip no less? What a peculiar idea! So I asked Tianxiao about it, and he recounted his story to me:

Yes! You might very well call it a hard trip! I left home just before noon and, having looked at the sky, it seemed to be clearing up. (...) Suddenly, the wind picked up and it started raining. I hadn't brought a rainproof coat that could have prevented me from getting wet.

So I borrowed an umbrella and just walked, ignoring the water seeping into my shoes. (...) When the boat reached midstream, the mast broke, and the sail fell down too. The mast was almost lying on the cabin and the boat itself nearly capsized. Everybody suddenly became scared. (...) I followed five or six tough guys who were also disembarking here. Alas! I was not as tough as them, and they kept moving forward at such a fast pace that you'd believe they were walking with four feet. At some point, I was totally unable to follow them, not to mention the fact that my sandals were muddy because of all the rain that had been falling on the bank. (...) A powerful wind rose over this desolate land; it was blowing so hard, as if it were about to crush everything around and throw everybody on the ground. I screamed stormily: "What should I do!" I painfully managed to get my feet move forward, and doing my best to look in all directions, I finally saw a house under a spring tree. I staggered in its direction and walked straight into the house. Short of breath, I politely asked the way to the Zou School. (...) After a very long while, I eventually saw the roofs of a village some distance away. It was like reaching the Cape of Cood Hope. However, all the doors were closed, so I had no choice but to knock and call for help. Dogs were barking at me when suddenly an old woman came out and asked me what I wanted. I explained everything to her. She sympathised with me and had two kids guide me around the countryside. (...) When I finally reached the school, I was panting like a cow and it took me quite a while before I managed to catch my breath and regain my ability to speak. Shuangre, who felt very bad about it and sympathised with me, wanted to remember this trip and so put it in the form of a poem:

Amid wind and rain he lost his way while night was falling,

On the slippery and muddy ground he could not walk.

He tried to ask for help,

No one has ever experienced such hardship!"

the glorious memory of the Xinhai Revolution. However, their numerous war-related short stories displayed an ambiguous assessment of revolutionary episodes in history. Revolutions did bring chaos and destroyed individual lives. Yet political participation did not always fulfil its promises of emancipation and self-realisation. In the wake of this reflection, which is mostly displayed in their short stories, they gave an unprecedented emphasis on depictions of the intimate. In this article, I claim that this "turn to the intimate" (be it about their own private lives or those of their friends) brought about a new trend in the Chinese political thinking of the early 1910 s.
I Joachim Boittout is a PhD candidate in History at the École des Hautes Études en Sciences Sociales (EHESS) in Paris. He is currently a visiting scholar at the Institute of Modern History of Academia Sinica (Taiwan). He teaches Classical and Modern Chinese at the Institut national des langues et civilisations orientales (Inalco) in Paris (joachim.boittout@ehess.fr). 


\section{References}

BAO, Tianxiao 包天笑. 1999. 釧影樓回憶錄 (Chuanyinglou huiyilu, Memoirs from the Bracelet's Shadow Tower). Taiyuan: Shanxi jiaoyu chubanshe and Shanxi guji chubanshe.

BÄRTHLEIN, Thomas. 1999. "'Mirrors of Transition': Conflicting Images of Society in Change from Popular Chinese Social Novels, 1908 to 1930." Modern China 25(2): 204-28.

CAl, Dengshan 蔡登山 (ed.). 2017. 求幸福齋隨筆: 民初報人何海鳴的時政 評論 (Qiu Xingfuzhai suibi: Minchu baoren He Haiming de shizheng pinglun, Notes from the Happiness Pursuer's Pavillion: Early Republican Journalist He Haiming's Political Commentaries). Taipei: Xinrui wenchuang.

CHEN, Jianhua 陳建華. 2015. 文以載車: 民國火車小傳 (Wen yi zaiche: Minguo huoche xiaozhuan, Rails on Books: A Concise History of Republican Trains). Shanghai: Shangwu yinshuguan.

CHEN, Jianhua 陳建華. 2008. "Canon Formation and Linguistic Turn: Literary Debates in Republican China, 1919-1949." In Kai-wing Chow, Tze ki Hon, Hung-yok Ip, and C. Price Don (eds.), Beyond May Fourth Paradigm: In Search of Chinese Modernity. Lanham: Lexington. 51-68.

CHOW, Tse-tsung. 1960. The May Fourth Movement: Intellectual Revolution in Modern China. Cambridge: Harvard University Press.

FANG, Ping 方平. 2001. “清末上海民間報刊與公眾䫡論的表達模式” (Qingmo Shanghai minjian baokan yu gongzhong yulun de biaoda moshi, Modes of expression of Late Qing Shanghai popular press and public sphere).二十一世界雙月刊 Ershiyi shiji shuangyuekan, 2001年2月號 (總 第六十三期).

FENG, Liping. 1996. "Democracy and Elitism: The May Fourth Ideal of Literature." Modern China 22(2): 170-96.

HSIA, C.T. 1982. "Hsu Chen-ya's Yu-li hun: An Essay in Literary History and Criticism." Renditions 17 and 18.

HOCKX, Michel. 2003. Questions of Style: Literary Societies and Literary Journals in Modern china 1911-1937. Leiden: Brill.
LEE, Haiyan. 2007. Revolution of the Heart: A Genealogy of Love in China, 1900-1950. Stanford: Stanford University Press.

LINK, Perry. 1981. Mandarin Ducks and Butterflies: Popular Fiction in Early Twentieth-Century Chinese Cities. Berkeley: The University of California Press.

NG, Kenny Kwok-kwan. 2015. The Lost Geopoetic Horizon of Li Jieren: The Crisis of Writing Chengdu in Revolutionary China. Leiden: Brill.

REED, Christopher A. 2004. Gutenberg in Shanghai: Chinese Print Capitalism 1876-1937. Vancouver: University of British Columbia Press.

SHEN, Songqiao 沈松橋. 1986. “五四時期章士釗的保守思想” (Wusi shiqi Zhang Shizhao de baoshou sixiang, Zhang Shizhao's conservatism during the May Fourth period). Zhongyang yanjiu yuan jindai shi yanjiu suojikan 15(2).

WAGNER, Rudolf G (ed.). 2007. Joining The Global Public: Word, Image, and City in Early Chinese Newspapers. Albany: State University of New York Press.

WANG, David Der-wei. 1997. Fin-de-siècle Splendor: Repressed Modernities of Late Qing Fiction 1848-1911. Stanford: Stanford University Press.

WANG, Hui 汪暉. 2013. "The Transformation of Culture and Politics: War, Revolution and the 'Thought Warfare of the 1910s'." Twentieth-Century China 38.

WANG, Xiaoming 王曉明. 1999. "A Journal and a 'Society': On the 'May Fourth' Literary Tradition." Modern Chinese Literature and Culture 11(2): $1-39$.

WESTON, Timothy B. 1998. "The Formation and Positioning of the New Culture Community, 1913-1917." Modern China 24(3): 255-284.

XU, Jilin 許紀霖. 2011. 啟蒙如何起死回生 (Qimeng ruhe qisihuisheng, How did Enlightenment Resurrect). Beijing: Beijing daxue chubanshe.

YOUNG, Ernest P. 1977. The Presidency of Yuan Shih-k'ai: Liberalism and Dictatorship in Early Republican China. Ann Arbor:The University of Michigan Press. 